\title{
THE EFFECT OF ETHANOL ON FATTY ACID METABOLISM; STIMULATION OF HEPATIC FATTY ACID SYNTHESIS IN VITRO *
}

\author{
By CHARLES S. LIEBER † AND RUDI SCHMID \\ (From the Thorndike Memorial Laboratory and Second and Fourth (Harvard) Medical \\ Services, Boston City Hospital, and the Department of Medicine, Harvard \\ Medical School, Boston, Mass.)
}

(Submitted for publication May 19, 1960 ; accepted October 20, 1960)

Fatty infiltration of the liver is a common finding in alcoholic patients, but the mechanisms responsible for the accumulation of hepatic fat are not clear (2). In the present investigation, an attempt was made to clarify this relationship by studying the effect of ethanol on fatty acid metabolism in rat liver in vitro (3).

\section{MATERIALS AND METHODS}

Seventy-one male Sprague-Dawley rats weighing from 250 to $400 \mathrm{~g}$ were maintained on Purina Laboratory Chow, except for a 24 hour period immediately precęding the experiment. During this period, they were given 36.5 $\mathrm{g}$ glucose per $\mathrm{kg}$ together with $7.5 \mathrm{~g}$ ethanol per $\mathrm{kg}$ or, in the experiment shown in Table III, $50 \mathrm{~g}$ per $\mathrm{kg}$ fructose, administered by means of 5 gastric tube feedings of equal volume. Approximately 3 hours after the last gastric feeding, the animals were decapitated. The liver was quickly removed, and slices were prepared in the cold with a Stadie-Riggs slicer (4). The $\mathrm{C}^{14}$-labeled ${ }^{1}$ and unlabeled substrates were dissolved in $5 \mathrm{ml}$ isotonic KrebsRinger bicarbonate buffer, $\mathrm{pH} 7.4$ (6), and the final concentration of the substrates was expressed as millimoles per liter. An aliquot of each incubation mixture was added to a toluene solution containing 12 per cent methanol, 0.4 per cent diphenyloxazole (DPO) and 0.005 per

* Presented in part at the Annual Meeting of the Central Society for Clinical Research, Chicago, Nov. 6, 1959 (1). This study was supported by Research Grant A-1833 (C) United States Public Health Service, The Nutrition Foundation, Inc., and the U. S. Army Medical Research and Development Command, Department of the Army (Contract DA-49-193-MD-2013).

$\dagger$ Aspirant du Fonds National Belge de la Recherche Scientifique and Fellow of the Belgian American Educational Foundation; Research Fellow in Medicine, Harvard Medical School and Thorndike Memorial Laboratory.

1 The following $\mathrm{C}^{14}$-labeled substrates were used: acetate-1- $\mathrm{C}^{14}$, acetate-2- $\mathrm{C}^{14}$, ethanol-1- $\mathrm{C}^{14}$, ethanol-2- $\mathrm{C}^{14}$, and palmitate-1-C $\mathrm{C}^{\mathbf{1 4}}$, the latter being bound to crystalline bovine albumin (5). The various substrates were purchased from New England Nuclear Corp., Boston, Mass., and Tracerlab, Inc., Waltham, Mass. cent 1,4-di-[2-(5 phenyloxazolyl)] benzene (POPOP) (7) and the radioactivity counted in a Packard liquid scintillation counter. Randomized liver slices (approximately $0.5 \mathrm{~g}$ ) were suspended in the incubation mixture in the main compartment of incubation flasks (8). The flasks were sealed with serum caps, gassed five minutes with a mixture of 95 per cent $\mathrm{O}_{2}$ and 5 per cent $\mathrm{CO}_{2}$, and then incubated for 3 hours at $37.5^{\circ} \mathrm{C}$ in a Dubnoff shaking water bath. Rat epididymal fat pads $(0.5$ to $1.0 \mathrm{~g})$ were incubated in the same manner. At the end of the incubation, $0.2 \mathrm{ml}$ of $10 \mathrm{~N}$ sulfuric acid was injected with a needle through the serum cap into the main compartment, and $1 \mathrm{ml}$ of alkaline hyamine (9) into the center well. The flasks were then shaken for 30 minutes in an ice bath to trap the evolving $\mathrm{CO}_{2}$ in the hyamine. The hyamine- $\mathrm{C}^{14} \mathrm{O}_{2}$ solution was transferred into a volumetric flask and made up to $5 \mathrm{ml}$ with toluene; $2 \mathrm{ml}$ of this solution was mixed with $16 \mathrm{ml}$ of toluene containing 0.4 per cent DPO and 0.005 per cent POPOP (9), and the radioactivity was measured in a Packard liquid scintillation counter. To calculate the disintegrations per minute $(\mathrm{dpm})$, the obtained counts were multiplied by the efficiency of the counter which was determined separately for each experiment with an internal $\mathrm{C}^{14}$ standard. $\mathrm{C}^{: 4} \mathrm{O}_{2}$ was expressed in dpm per gram of wet tissue or per milligram of tissue nitrogen.

The incubated tissue from each flask was homogenized in the incubation mixture, and an aliquot of this homogenate was used for determination of total nitrogen by the micro-Kjeldahl method (10). The rest of the homogenate was transferred to a screw-capped bottle, to which $0.4 \mathrm{ml}$ of 90 per cent ( $\mathrm{wt} / \mathrm{vol}$ ) potassium hydroxide per $\mathrm{ml}$ of homogenate was added. This mixture was saponified by autoclaving for 1 hour at $120^{\circ} \mathrm{C}$. After cooling, ethanol was added to obtain a final concentration of 50 per cent. The mixture was vigorously shaken with $20 \mathrm{ml}$ petroleum ether for 10 minutes to remove nonsaponifiable material. After repeating the extraction with petroleum ether 3 times, the ethanol remaining in the aqueous phase was removed by heating on a steam bath, and the $\mathrm{pH}$ was reduced to below 3.0 with concentrated sulfuric acid. After cooling, the fatty acids were extracted with $20 \mathrm{ml}$ petroleum ether. The extraction was repeated 3 times, and the ether extracts were pooled and washed twice with water. An aliquot of the washed ether extract was evaporated under a nitrogen stream, and the dry residue was used for estimation of total fatty 
acids (11). The results were expressed in milligrams of palmitic acid per milligram of tissue nitrogen. Using this method, about 95 per cent of palmitic acid added to homogenized liver slices was recovered. Another dried aliquot was dissolved in toluene containing 0.4 per cent of DPO and 0.005 per cent of POPOP, and the radioactivity of the fatty acids was determined in a Packard liquid scintillation counter. The labeling of fatty acids was expressed in dpm per milligram of tissue nitrogen. To permit comparison of the results obtained with different substrates and substrate concentrations, incorporation of $\mathrm{C}^{14}$ into fatty acids was also expressed as percentage of the $\mathrm{C}^{14} \mathrm{O}$., evolved; labeling expressed in this way will subsequently be called "relative incorporation." In all experiments, control incubations were carried out with acid-inactivated liver slices.

In each experiment, tissues obtained from the same animal were used for comparison of the effect of the various substrates. The mean of the individual differences was calculated and its degree of significance was tested by the $t$ test (12).

\section{RESULTS}

1. Total fatty acid content of liver slices incubated with ethanol, acetate or glucose. After incubation for 3 hours, the total fatty acid content of rat liver slices averaged $0.885 \mathrm{mg}$ palmitic acid per $\mathrm{mg}$ tissue nitrogen when incubated with 10 $\mathrm{mM}$ ethanol, and $0.805 \mathrm{mg}$ palmitic acid on incubation with $10 \mathrm{mM}$ acetate. In 17 paired determinations, the mean difference was $0.080 \pm 0.029$ $\mathrm{mg}$ palmitic acid per $\mathrm{mg}$ tissue nitrogen $(\mathrm{p}<$ $0.02)$.

In nine instances, slices were incubated with either $10 \mathrm{mM}$ ethanol or $5 \mathrm{mM}$ glucose. At the

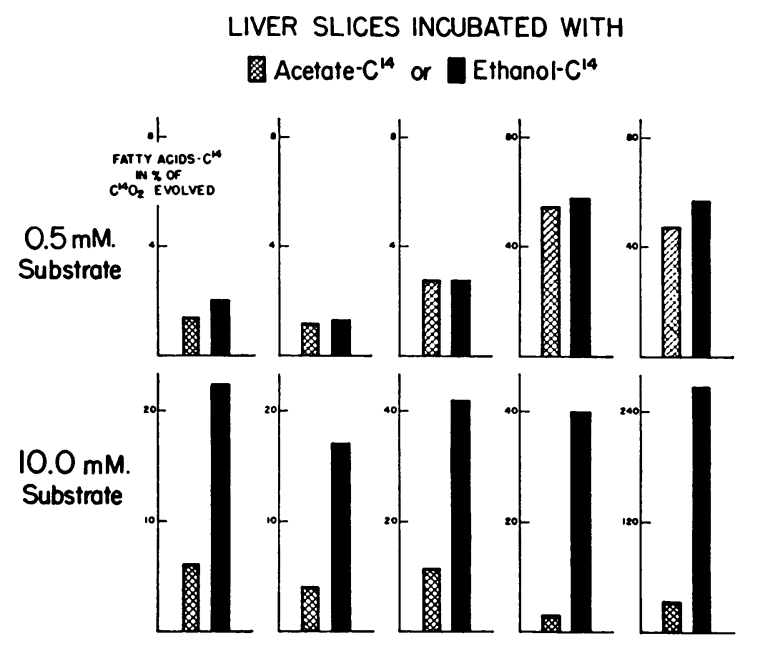

Fig. 1. Labeling of FatTy acids IN LIVER SLICES IN-

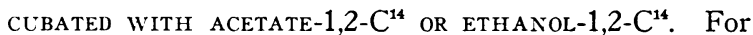
both ethanol and acetate, the specific activity was $1.3 \mathrm{mc}$ per mmole at the lower substrate concentration $(0.5 \mathrm{mM})$, and $0.033 \mathrm{mc}$ per mmole at the higher substrate concentration $(10 \mathrm{mM})$. The results are expressed as fatty acids- $\mathrm{C}^{14}$ in per cent of $\mathrm{C}^{14} \mathrm{O}_{2}$ evolved (relative incorporation).

end of the incubation period, the total fatty acid content of the slices was on the average $0.901 \mathrm{mg}$ palmitic acid per mg of tissue nitrogen in the presence of ethanol, and $0.831 \mathrm{mg}$ palmitic acid. with glucose. The mean difference was $0.070 \pm 0.021$ $\mathrm{mg}$ palmitic acid per $\mathrm{mg}$ of tissue nitrogen $(\mathrm{p}<$ $0.02)$.

2. Incubation of liver slices and adipose tissue with acetate-1,2-C $C^{14}$ or ethanol $-1,2-C^{14}$. As seen

TABLE I

Incubation of rat liver slices *

\begin{tabular}{|c|c|c|c|c|c|}
\hline \multicolumn{3}{|c|}{$\begin{array}{l}\text { With } 0.33 \mu \mathrm{c} / \mathrm{ml} \text { acetate-1- } \mathrm{C}^{14} \text { and } \\
10 \mathrm{mM} \text { unlabeled acetate }\end{array}$} & \multicolumn{3}{|c|}{$\begin{array}{c}\text { With } 0.33 \mu \mathrm{c} / \mathrm{ml} \text { acetate-1-C } \mathrm{C}^{14} \text { and } \\
10 \mathrm{mM} \text { unlabeled ethanol }\end{array}$} \\
\hline \multirow{2}{*}{$\frac{\mathrm{C}^{1+\mathrm{O}_{2}}}{\mathrm{dpm/mg} \mathrm{N}}$} & \multicolumn{2}{|c|}{ Fatty acids- $\mathrm{C}^{14}$} & \multirow{2}{*}{$\frac{\mathrm{C}^{14} \mathrm{O}_{2}}{d p m i m g . V}$} & \multicolumn{2}{|c|}{ Fatty acids- $\mathrm{C}^{14}$} \\
\hline & dpmimg N & $\%$ of $\mathrm{C}^{14} \mathrm{O}_{2} \dagger$ & & $d p m i m g . V$ & $\mathrm{C}$ of $\mathrm{C}^{11} \mathrm{O}_{2}$ \\
\hline 25,940 & 1,260 & 4.9 & 9,300 & 14,500 & 155.9 \\
\hline 19,940 & 1,260 & 6.3 & 15,330 & 6,570 & +2.9 \\
\hline 33,540 & 2,870 & 5.8 & 9,950 & 1,180 & 11.9 \\
\hline 26,390 & 1,390 & 5.3 & 15,810 & 2,090 & 13.2 \\
\hline 34,180 & 1,850 & 5.4 & 19,060 & 6,040 & 31.7 \\
\hline 2,340 & 230 & 9.6 & 7,170 & 1,340 & 18.7 \\
\hline 19,840 & 3,660 & 18.4 & 20,700 & 6,190 & 29.9 \\
\hline 34,070 & 1,700 & 5.0 & 18,920 & 6,290 & 33.2 \\
\hline 25,560 & 400 & 1.6 & 21,550 & 2,740 & 12.7 \\
\hline 20,470 & 250 & 1.2 & 15,580 & 3,400 & 21.9 \\
\hline 32,090 & 970 & 3.0 & 11,730 & 5,270 & 44.9 \\
\hline 5,030 & 1,640 & 32.7 & 12,740 & 23,070 & 181.1 \\
\hline
\end{tabular}

* In this and in all subsequent tables, results given on the same horizontal line were obtained with tissue from the same rat.

$+\mathrm{C}^{14}$ in fatty acids $\times 100 / \mathrm{C}^{14}$ in $\mathrm{CO}_{2}$. 
in Figure 1, at a substrate concentration of 0.5 $\mathrm{mM}$, relative incorporation of acetate-1,2- $\mathrm{C}^{14}$ (1.3 mc per mmole) and of ethanol-1,2- ${ }^{14}(1.3 \mathrm{mc}$ per mmole) into fatty acids of liver slices was similar for each individual rat, although considerable variation was observed between different animals.

With a substrate concentration 20 times higher, however ( $10 \mathrm{mM} ; 0.033 \mathrm{mc}$ per mmole), the relative incorporation of the label from ethanol-1,2- $\mathrm{C}^{14}$ into fatty acids was 3 to 12 times higher than with acetate-1,2-C ${ }^{14}$ (Figure 1).

Adipose tissue of 8 rats was incubated with either $0.5 \mathrm{mM}$ ethanol-1,2-C ${ }^{14}$ or $0.5 \mathrm{mM}$ acetate$1,2-\mathrm{C}^{14}$ (1.3 mc per mmole). With ethanol- $\mathrm{C}^{14}$, much less $\mathrm{C}^{14} \mathrm{O}_{2}$ was produced than with acetate$\mathrm{C}^{14}$, the respective values being $156 \pm 58 \mathrm{dpm}$ per $\mathrm{mg}$ of tissue nitrogen against $1,787 \pm 306 \mathrm{dpm}$.

3. Effect of unlabeled substrates on the metabolism of acetate-1-C $\mathrm{C}^{\mathbf{1 4}}$ in liver slices and adipose tissue. The results in Tables I and II indicate that on incubation of liver slices with $0.33 \mu \mathrm{c}$ per $\mathrm{ml}$ acetate-1- $\mathrm{C}^{14}$ (specific activity of the undiluted acetate-1-C $\mathrm{C}^{14}: 1 \mathrm{mc}$ per mmole), incorporation of the label into fatty acids was approximately four times higher in the presence of $10 \mathrm{mM}$ unlabeled ethanol than with $10 \mathrm{mM}$ unlabeled acetate $(\mathrm{p}<$ 0.001 ). With $10 \mathrm{mM}$ unlabeled ethanol, the relative incorporation of the label into fatty acids was approximately six times greater than with $10 \mathrm{mM}$ unlabeled acetate and three times greater than with $5 \mathrm{mM}$ unlabeled glucose (Figure 2).
LIVER SLICES

INCUBATED WITH $0.33 \mu \mathrm{C} / \mathrm{mL}$. ACETATE-I-C 14

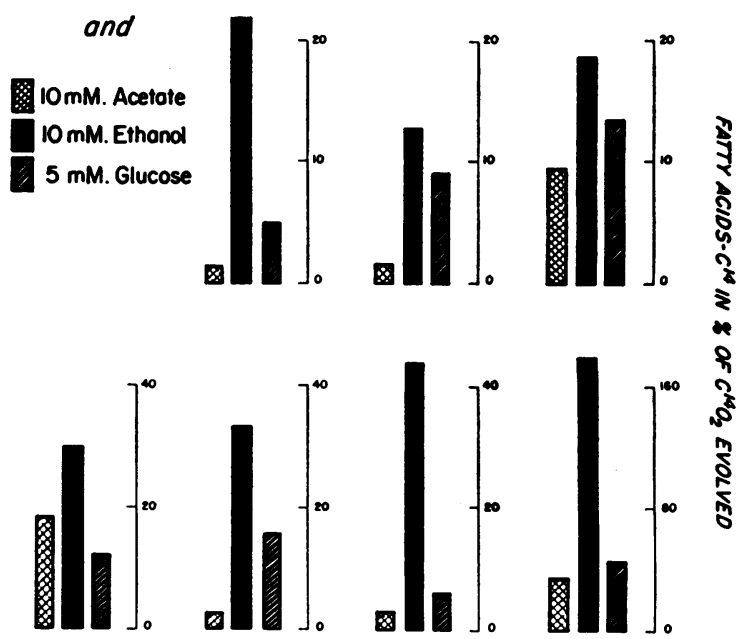

Fig. 2. Effect of UNLABeled acetate, ethanol oR GLUCOSE ON THE RELATIVE INCORPORATION OF ACETATE-1-C ${ }^{\mathbf{1 4}}$ INTO FATTY ACIDS IN LIVER SLICES.

As seen in Table II, incubation of liver slices in the presence of $0.6 \mathrm{mM}$ methylene blue resulted in decreased incorporation of the label into fatty acids in all experiments. It reduced in part the stimulatory effect of ethanol on the relative incorporation of the label into fatty acids.

In adipose tissue, no stimulatory effect was observed with ethanol, while glucose enhanced acetate-1- $\mathrm{C}^{14}$ incorporation into fatty acids (Figure $3)$.

TABLE II

Effect of methylene blue on incubation of rat liver slices

\begin{tabular}{|c|c|c|c|c|c|c|}
\hline \multicolumn{4}{|c|}{$\begin{array}{l}\text { With } 0.33 \mu \mathrm{c} / \mathrm{ml} \text { acetate- } 1-\mathrm{C}^{14} \text { and } \\
10 \mathrm{mM} \text { unlabeled acetate }\end{array}$} & \multicolumn{3}{|c|}{$\begin{array}{l}\text { With } 0.33 \mu \mathrm{c} / \mathrm{ml} \text { acetate-1- } \mathrm{C}^{14} \text { and } \\
10 \mathrm{mM} \text { unlabeled ethanol }\end{array}$} \\
\hline$\overline{\text { Rat }}$ & \multirow{2}{*}{$\begin{array}{c}\mathrm{C}^{14} \mathrm{O}_{2} \\
d p m / m g N\end{array}$} & \multicolumn{2}{|c|}{ Fatty acids-C 14} & \multirow{2}{*}{$\begin{array}{c}\mathrm{C}^{14} \mathrm{O}_{2} \\
d p m / m g N\end{array}$} & \multicolumn{2}{|c|}{ Fatty acids- $\mathrm{C}^{14}$} \\
\hline Wi & & $d p m / m g N$ & $\%$ of $\mathrm{C}^{14} \mathrm{O}_{2} *$ & & $d p m / m g N$ & $\%$ of $\mathrm{C}^{14} \mathrm{O}_{2}$ \\
\hline $\begin{array}{l}a \\
b \\
c \\
d \\
e\end{array}$ & $\begin{array}{l}35,410 \\
47,920 \\
38,540 \\
44,820 \\
15,540\end{array}$ & $\begin{array}{r}5,840 \\
9,040 \\
4,804 \\
1,640 \\
317\end{array}$ & $\begin{array}{r}16.5 \\
18.9 \\
12.5 \\
3.7 \\
2.0\end{array}$ & $\begin{array}{l}22,620 \\
30,190 \\
28,990 \\
34,520 \\
10,570\end{array}$ & $\begin{array}{r}25,520 \\
20,120 \\
9,910 \\
13,540 \\
9,100\end{array}$ & $\begin{array}{r}112.8 \\
66.6 \\
46.1 \\
39.2 \\
86.1\end{array}$ \\
\hline \multicolumn{7}{|c|}{ With $0.6 \mathrm{mM}$ methylene blue } \\
\hline $\begin{array}{l}\mathrm{a} \\
\mathrm{b} \\
\mathrm{c} \\
\mathrm{d} \\
\mathrm{e}\end{array}$ & $\begin{array}{r}25,590 \\
29,530 \\
10,790 \\
36,690 \\
8,850\end{array}$ & $\begin{array}{r}710 \\
1,240 \\
430 \\
230 \\
132\end{array}$ & $\begin{array}{l}2.8 \\
4.2 \\
3.9 \\
0.6 \\
1.5\end{array}$ & $\begin{array}{l}29,560 \\
33,070 \\
27,910 \\
41,890 \\
21,180\end{array}$ & $\begin{array}{r}3,500 \\
4,270 \\
2,000 \\
920 \\
890\end{array}$ & $\begin{array}{r}11.8 \\
12.9 \\
7.2 \\
2.2 \\
4.2\end{array}$ \\
\hline
\end{tabular}

${ }^{*} \mathrm{C}^{14}$ in fatty acids $\times 100 / \mathrm{C}^{14}$ in $\mathrm{CO}_{2}$. 
ADIPOSE TISSUE

INCUBATED WITH $0.33 \mu \mathrm{C} / \mathrm{mL}$. ACETATE-I-C ${ }^{14}$

and

$10 \mathrm{mM}$. Acetote
$10 \mathrm{mM}$. Ethanol
$5 \mathrm{mM}$. Glucose
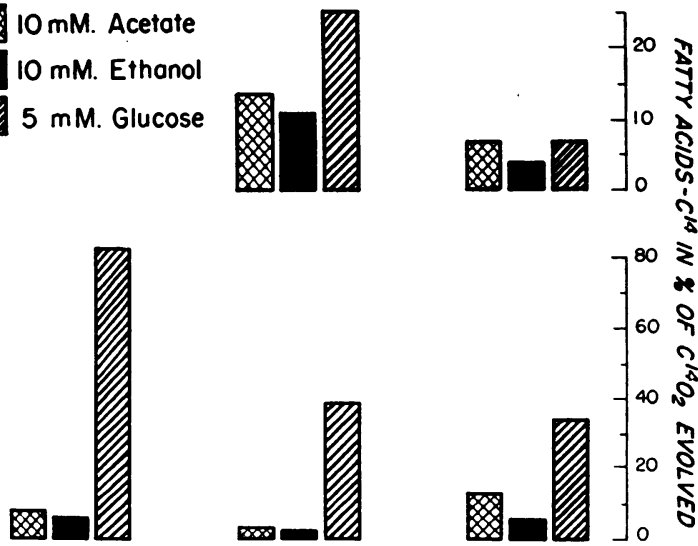

Fig. 3. Effect of Unlabeled acetate, ethanol or GLUCOSE ON THE RELATIVE INCORPORATION OF ACETATE-1-C ${ }^{\mathbf{1 4}}$ INTO FATTY ACIDS IN ADIPOSE TISSUE.

The results of Table III indicate that in the presence of unlabeled sorbitol, incorporation of the label into fatty acids of liver slices was two to five times higher than with equimolar amounts of unlabeled fructose.

4. Effect of ethanol on the $\mathrm{C}^{14} \mathrm{O}_{2}$ production from palmitate-1-C $C^{14}$ and acetate-1- $C^{1+}$ in liver slices. Liver slices were incubated with 0.03 , 0.04 or $0.06 \mu \mathrm{c}$ per $\mathrm{ml}$ palmitate-1- $\mathrm{C}^{14}$ ( $1 \mathrm{mc}$ per mmole), supplemented with either $10 \mathrm{mM}$ unlabeled acetate or $10 \mathrm{mM}$ unlabeled ethanol.

On incubation with ethanol, the average $\mathrm{C}^{14} \mathrm{O}_{2}$ formation in 14 experiments was $30,900 \mathrm{dpm}$ per $\mathrm{g}$ of tissue and on incubation with acetate, 58,500 $\mathrm{dpm}$. The mean difference was $27.600 \pm 10,500$ $\mathrm{dpm}$ per $\mathrm{g}$ of tissue $(\mathrm{p}<0.05)$. When, under

\section{$\mathrm{C}^{14} \mathrm{O}_{2}$ PRODUCTION IN RAT LIVER SLICES}

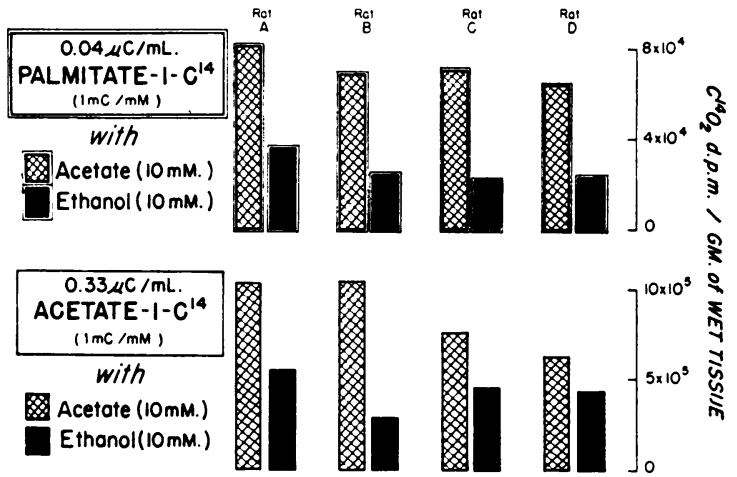

Fig. 4. Effect of Unlabeled ethanol or acetate ON $\mathrm{C}^{14} \mathrm{O}$ : PRODUCTION BY RANDOMIZED LIVER SLICES, INCUbated With either acetate-1-C ${ }^{14}$ or Palmitate-1- ${ }^{14}$.

similar experimental conditions, palmitate-1- $\mathrm{C}^{14}$ was replaced by acetate $-1-\mathrm{C}^{14}$ (Tables I and II), the average $\mathrm{C}^{14} \mathrm{O}_{2}$ production was $304,700 \mathrm{dpm}$ per $\mathrm{mg}$ of tissue nitrogen in the presence of unlabeled ethanol and 461,600 dpm with unlabeled acetate. The mean difference in 17 experiments was $156,900 \pm 9.200 \mathrm{dpm}$ per $\mathrm{mg}$ of tissue nitrogen $(\mathrm{p}<0.001)$.

In four instances when randomized liver slices obtained from the same animal were used to study the effect of $10 \mathrm{mM}$ ethanol on $\mathrm{C}^{14} \mathrm{O}_{2}$ production from both palmitate-1- $\mathrm{C}^{14}$ and from acetate-1- $\mathrm{C}^{14}$, the reduction in $\mathrm{C}^{14} \mathrm{O}_{2}$ formation was comparable with both labeled sulsstrates (Figure 4).

\section{DISCUSSION}

The total fatty acid content of liver slices incubated for 3 hours with ethanol was found to be significantly higher as compared to incubation

TABLE III

Incubation of rat liver slices

\begin{tabular}{|c|c|c|c|c|c|}
\hline \multicolumn{3}{|c|}{$\begin{array}{l}\text { With } 0.33 \mu \mathrm{c} / \mathrm{ml} \text { acetate-1-C } \mathrm{C}^{14} \text { and } \\
60 \mathrm{mM} \text { unlabeled fructose }\end{array}$} & \multicolumn{3}{|c|}{$\begin{array}{l}\text { With } 0.33 \mu \mathrm{c} / \mathrm{ml} \text { acetate-1- } \mathrm{C}^{14} \text { and } \\
60 \mathrm{mM} \text { unlabeled sorbitol }\end{array}$} \\
\hline \multirow{2}{*}{$\frac{\mathrm{C}^{14} \mathrm{O}_{2}}{d p m / m g N}$} & \multicolumn{2}{|c|}{ Fatty acids- $\mathrm{C}^{14}$} & \multirow{2}{*}{$\frac{\mathrm{C}^{14} \mathrm{O}_{2}}{d p m / m g \mathrm{~N}}$} & \multicolumn{2}{|c|}{ Fatty acids- ${ }^{14}$} \\
\hline & $d p m / m g N$ & $c /$ of $\mathrm{C}^{14} \mathrm{O}_{2} *$ & & $d p m / m g N$ & \% of $\mathrm{C}^{14} \mathrm{O}_{2}$ \\
\hline 58,180 & 28,920 & 49.7 & 55,660 & 69,640 & 125.1 \\
\hline 69,280 & 19,120 & 27.5 & 73,280 & 70,860 & 96.7 \\
\hline 62,300 & 20,670 & 33.2 & 72,890 & 53,380 & 73.2 \\
\hline 62,930 & 32,070 & 51.0 & 71,090 & 81,960 & 115.2 \\
\hline 33,840 & 11,810 & 34.9 & 33,180 & 49,920 & 150.0 \\
\hline 37,590 & 7,320 & 19.5 & 49,670 & 46,920 & 94.5 \\
\hline
\end{tabular}

${ }^{*} \mathrm{C}^{14}$ in fatty acids $\times 100 / \mathrm{C}^{14}$ in $\mathrm{CO}_{2}$. 
with glucose or acetate. In the subsequent experiments, an attempt was made to clarify the mechanism responsible for this finding.

The results in Figure 1 indicate that at a substrate concentration of $0.5 \mathrm{mM}$, the relative incorporation of ethanol- $\mathrm{C}^{14}$ and acetate- $\mathrm{C}^{14}$ into hepatic fatty acids was similar, while with a substrate concentration 20 times higher, relative incorporation into fatty acids was 3 to 12 times higher with ethanol- $\mathrm{C}^{14}$ as compared with acetate$\mathrm{C}^{14}$. Similarly, when liver slices were incubated with acetate- $\mathrm{C}^{14}$ and either $10 \mathrm{mM}$ unlabeled ethanol or unlabeled acetate (Table I), ethanol enhanced the incorporation of acetate- $\mathrm{C}^{14}$ into fatty acids and reduced the production of $\mathrm{C}^{14} \mathrm{O}_{2}$. Interpretation of these findings is complicated by the variable dilution of the label by the unlabeled substrates and also by possible differences in the rate of metabolism between ethanol and acetate. However, since both for incorporation into fatty acids and for conversion to $\mathrm{CO}_{2}$ via the tricarboxylic acid cycle (TCA), acetate and ethanol pass through a common acetyl-CoA pool (13) and since the total disposition of acetate- $\mathrm{C}^{14}$ into both lipids and $\mathrm{CO}_{2}$ was approximately of the same order of magnitude (Table I), the present findings may suggest that on incubation with ethanol, utilization of acetyl-CoA is shifted in such a way that a relatively larger fraction is incorporated into fatty acids while less is metabolized via the TCA cycle.

In adipose tissue, where lack of alcohol dehydrogenase activity prevents significant oxidation of ethanol $(3,14)$, ethanol failed to stimulate incorporation of acetate- $\mathrm{C}^{14}$ into fatty acids (Figure 3 ).

In the liver, ethanol is oxidized by alcohol dehydrogenase (15-17) with concomitant reduction of diphosphopyridine nucleotide (DPN) to DPNH (18). In vivo and in vitro, ethanol was found to reduce the hepatic DPN/DPNH ratio $(19,20)$.

Decreased concentration of DPNH in the liver was shown to be associated with reduced fatty acid synthesis (21), while in cell-free liver extracts, addition of exogenous DPNH was found to stimulate fatty acid synthesis $(22,23)$. These findings suggest that ethanol may enhance incorporation of acetate- $\mathrm{C}^{14}$ into hepatic fatty acids through the excess DPNH formed on ethanol ox- idation. It is not known, however, whether this occurs by reducing TCA cycle activity or by direct stimulation of fatty acid synthesis, or both.

Supportive evidence for this concept is obtained by the experiments with sorbitol-fructose (Table III) and with methylene blue (Table II). In the liver, oxidation of sorbitol to fructose is coupled with concomitant reduction of DPN to DPNH (24). The increased incorporation of acetate- $\mathrm{C}^{14}$ into fatty acids in the presence of sorbitol may be due to the shift in DPN/DPNH ratio (Table III). Conversely, the presence of a hydrogen acceptor, such as methylene blue, would be expected to offset the stimulatory effect of ethanol, such as is shown in Table II.

It has been shown in vitro that addition of DPNH results in reduced oxidation of TCA cycle intermediates (25). Thus, the excess DPNH generated on ethanol oxidation may account for the reduced formation of $\mathrm{C}^{14} \mathrm{O}_{2}$ from acetate- $\mathrm{C}^{14}$ (Tables I and II) and from palmitate-1-C $\mathrm{C}^{14}$ (Figure 4). The possibility cannot be excluded with certainty, however, that in addition to stimulating fatty acid synthesis, ethanol may exert an inhibitory effect on fatty acid oxidation.

\section{CONCLUSIONS AND SUMMARY}

1. The total fatty acid content of liver slices is significantly higher when incubated with ethanol than with glucose or acetate.

2. The incorporation of acetate- $\mathrm{C}^{14}$ into fatty acids of liver slices is stimulated by ethanol, as compared with acetate or glucose.

3 . In adipose tissue, where only small amounts of ethanol are oxidized, no stimulation of fatty acid synthesis by ethanol is observed.

4. In liver slices incubated with ethanol, $\mathrm{C}^{14} \mathrm{O}_{2}$ production from acetate-1- $\mathrm{C}^{14}$ and from palmitate$1-\mathrm{C}^{14}$ is depressed to a similar extent.

5. Oxidation of ethanol in the liver results in reduction of DPN and a shift in incorporation of acetate- $\mathrm{C}^{14}$ toward fatty acid synthesis. Another DPNH generating system (sorbitol-fructose) reproduces this effect, while methylene blue reverses it. These findings suggest that the stimulation of hepatic fatty acid synthesis by ethanol may be the result of the excess DPNH formed on ethanol oxidation. 


\section{ACKNOWLEDCiMENTS}

The authors are grateful to Drs. C. S. Davidson, N. Freinkel, C. J. Goodner and A. E. Renold for valuable help and advice. Expert technical assistance was rendered by Miss Leonore M. De Carli, Miss E. Doyle and Miss Donna G. Cardamone.

\section{REFERENCES}

1. Lieber, C. S., DeCarli, L. M., and Schmid, R. Effect of ethanol on fatty acid metabolism in vitro (abstract). J. Lab. clin. Med. 1959, 54, 919.

2. Davidson, C. S., and Popper, H. Cirrhosis in alcoholics. Amer. J. Med. 1959, 27, 193.

3. Lieber, C. S., DeCarli, L. M., and Schmid, R. Effect of ethanol on fatty acid metabolism in liver slices. Biochem. biophys. Res. Com. 1959, 1, 302.

4. Stadie, W. C., and Riggs, B. C. Microtome for the preparation of tissue slices for metabolic studies of surviving tissues in vitro. J. biol. Chem. 1944, 154, 687.

5. Milstein, S. W., and Driscoll, L. H. Oxidation of albumin-bound palmitate-1- $\mathrm{C}^{14}$ by adipose and hepatic tissues of the rat. J. biol. Chem. 1959, 234, 19.

6. Krebs, H. A., and Henseleit, K. Untersuchungen über die Harnstoffbildung im Tierkörper. Z. physiol. Chem. 1932, 210, 33.

7. Davidson, J. D., and Feilgelson, P. Practical aspects of internal-sample liquid-scintillation counting. Int. J. appl. Radiat. 1957, $2,1$.

8. Baruch, H., and Chaikoff, I. L. A simplified method for determination of lipide- $\mathrm{C}^{14}$ in liver. Proc. Soc. exp. Biol. (N. Y.) 1954, 86, 97.

9. Passmann, J. M., Radin, N. S., and Cooper, J. A. D. Liquid scintillation technique for measuring carbon-14-dioxide activity. Analyt. Chem. 1956, 28, 484.

10. Markham, R. A steam distillation apparatus suitable for micro-Kjeldahl analysis. Biochem. J. 1942, 36, 790.

11. Bragdon, J. H. Colorimetric determination of blood lipides. J. biol. Chem. 1951, 190, 513.

12. Snedecor, G. W. Statistical Methods Applied to Experiments in Agriculture and Biology. Ames, Iowa State College Press, 1946.
13. Westerfeld, W. W. The metabolism of alcohol. Texas Rep. Biol. Med. 1955, 13, 559.

14. Hollifield, G., Respess, J. C., and Parson, W. Lipid synthesis from C-14 labeled ethanol by rat liver and adipose tissue in zitro. Clin. Res. 1960, 8, 83.

15. Jacobsen, E. The metabolism of ethyl alcohol. Pharmacol. Rev. 1952, 4, 107.

16. Bartlett, G. R. Does catalase participate in the physiological oxidation of alcohols? Quart. J. Stud. Alcohol 1952, 13, 583.

17. Kinard, F. W., Nelson, G. H., and Hay, M. G. Catalase activity and ethanol metabolism in the rat. Proc. Soc. exp. Biol. (N. Y.) 1956, 92, 772.

18. Theorell, H., and Bonnichsen, R. Studies on liver alcohol dehydrogenase. I. Equilibria and initial reaction velocities. Acta chem. scand. 1951, 5, 1105.

19. Forsander, O., Räihä, N., and Suomalainen, H. Alkoholoxidation und Bildung von Acetoacetat in normaler und glykogenarmer intakter Rattenleber. Z. physiol. Chem. 1958, 312, 243.

20. Smith, M. E., and Newman, H. W. The rate of ethanol metabolism in fed and fasting animals. J. biol. Chem. 1959, 234, 1544.

21. Helmreich, E., Holzer, H., Lamprecht, W., and Goldschmidt, S. Bestimmung von stationären Zwischenstoffkonzentrationen. II. Die Entstehung der Ketokörper und ihre Beziehung zur Glykolyse. Z. physiol. Chem. 1954, 297, 113.

22. Porter, J. W., Wakil, S. J., Tietz, A., Jacob, M. I., and Gibson, D. M. Studies on the mechanism of fatty acid synthesis. II. Cofactor requirements of the soluble pigeon liver system. Biochim. biophys. Acta 1957, 25, 35.

23. von Brand, V., and Helmreich, E. Beziehungen der Glykolyse zum Fettstoffwechsel; die Transportfunktion der Pyridincoenzyme im Zusammenspiel von Glykolyse, Atmung und Fettsynthese. Biochem. Z. 1956, 328, 146.

24. Blakley, R. L. The metabolism and antiketogenic effects of sorbitol dehydrogenase. Biochem. J. 1951, 49, 257.

25. Lester, R. L., Ziegler, D. M., and Green, D. E. Studies on the mechanism of oxidative phosphorylation. II. Role of bound pyridine nucleotide in phosphorylation. Biochim. biophys. Acta 1957, 24, 155 . 